\title{
Convenient One-Pot Synthesis of Allylsilanes from Enolizable Ketones
}

\author{
Man Lung D. Kwan* (i) \\ Paul R. Challen \\ Quynh D.-D. Tran \\ Department of Chemistry, John Carroll University, \\ 1 John Carroll Blvd, University Heights, $\mathrm{OH} 44118$, USA \\ mlkwan@jcu.edu
}

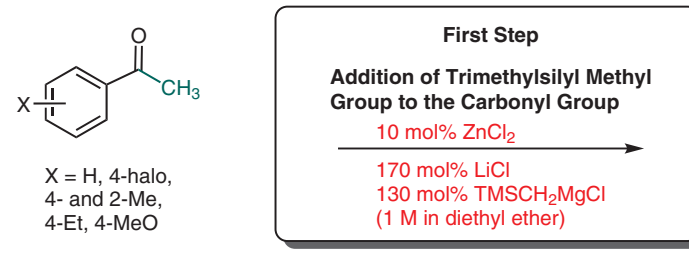

Second Step

Abnormal Peterson Olefination

1.4 equiv. $\left(\left(\mathrm{CH}_{3}\right)_{2} \mathrm{CHCH}_{2}\right)_{2} \mathrm{AICl}$

$20 \mathrm{~mL}$ THF, $130^{\circ} \mathrm{C}, 15 \mathrm{~h}$

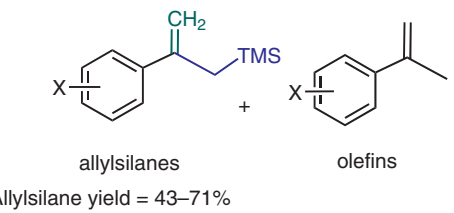

Received: 29.09.2019

Accepted after revision: 02.11.2019

Published online: 19.11 .2019

DOI: 10.1055/s-0039-1690335; Art ID: so-2019-d0028-I

License terms: $c(0) \$$

(c) 2019. The Author(s). This is an open access article published by Thieme under the terms of the Creative Commons Attribution-NonDerivative-NonCommercial-License, permitting copying and reproduction so long as the original work is given appropriate credit. Contents may not be used for commercial purposes or adapted, remixed, transformed or built upon. (https://creativecommons.org/licenses/by-nc-nd/4.0/)

Abstract A convenient one-pot synthesis of allylsilanes from enolizable methyl aryl ketones has been developed. The first step involves nucleophilic addition of the trimethylsilylmethyl group to ketones using the alkylation method developed by Ishihara with slight modification to generate the corresponding $\beta$-silylalkoxides. The second step entails addition of diisobutylaluminum chloride and heating at about $130{ }^{\circ} \mathrm{C}$ overnight to afford allylsilanes in fair yields.

Key words abnormal Peterson olefination, allylsilane, one-pot synthesis

Allylsilanes are versatile allylic anion equivalents. ${ }^{1,2}$ Unlike most allyl organometallic species such as allylic Grignard reagents, allylic rearrangement is not a concern for allylsilanes. Formation of the new bond via electrophilic reaction occurs regionspecifically at the $\gamma$-position of the allylsilane (Scheme 1). ${ }^{1 \mathrm{e}}$

$$
\left(\mathrm{H}_{3} \mathrm{C}\right)_{3} \mathrm{Si} \underbrace{\beta}_{\alpha} \aleph_{\gamma}
$$

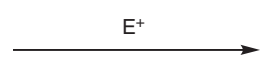

Scheme 1

Many allylsilane syntheses were reported during the 1990s. ${ }^{2}$ Most popular are transformations of alkenes; whereas transformations of carbonyl compounds into allylsilanes are scarce, although one obvious example utilizes the Wittig protocol to convert ketones or aldehydes. ${ }^{2 e}$ However, this method requires multiple synthetic steps starting from triphenylphosphine to furnish the corresponding allylsilane, and removing the triphenylphosphine oxide byproduct is challenging (Scheme 2$)^{3}$

$$
\mathrm{R}^{1} \stackrel{\text { II }}{\mathrm{R}^{2}}
$$$$
\mathrm{Ph}_{3} \mathrm{P}=\smile \mathrm{TMS}
$$

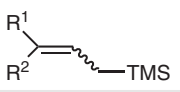

Scheme 2

Another example uses the Peterson olefination ${ }^{4}$ protocol to convert an ester into the desired allylsilane via loss of trimethylsilanol from the initial bis-adduct (Scheme 3). ${ }^{2 \mathrm{~d}}$

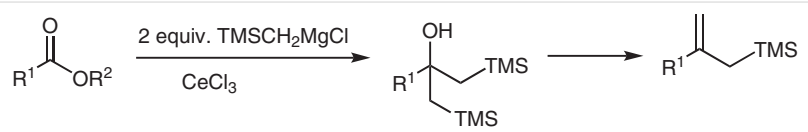

\section{Scheme 3}

The standard Peterson olefination converts $\beta$-hydroxysilanes into desilylated olefins under either acidic or basic conditions. Battiste and Kwan reported the use of alumoxanes in vinylsilane synthesis. ${ }^{5}$ The methodology employs a Peterson protocol to convert non-enolizable ketones into the corresponding vinylsilanes. Since the silyl group is intact during the elimination, these are referred to as abnormal Peterson olefinations. Doxsee and Kwan extended the vinylsilane synthesis, starting from non-enolizable aryl aldehydes via the abnormal Peterson olefination. ${ }^{6}$ Instead of using alumoxanes as amphoteric reagents, Doxsee and Kwan used the Tebbe reagent for the elimination step. Kwan's subsequent work revealed that an additional Lewis acid such as the titanium in Tebbe's reagent assists the deoxygenation. ${ }^{7}$ We report herein the use of the abnormal Peterson protocol to convert enolizable ketones into allylsilanes in a convenient two-step, one-pot reaction. Alkylating 
enolizable ketones and aldehydes is often challenging because it can give undesired products such as self-aldol condensation products. Several synthetic methods have been developed to alkylate enolizable ketones and aldehydes effectively. ${ }^{8}$ Recognizing the ability of $\mathrm{Zn}^{2+}$ to cleave carbonoxygen bonds, ${ }^{9}$ we have employed the alkylation method, using $\mathrm{ZnCl}_{2}$, developed by Ishihara et al. ${ }^{8 \mathrm{~d}}$ for our first reaction step with slight modification.

In Ishihara's method, the $\left(\mathrm{CH}_{3}\right)_{3} \mathrm{SiCH}_{2}$ group $(20 \mathrm{~mol} \%)$ was used as a non-transferable ligand in the catalytic alkylzinc(II) ate complex and to enhance its catalytic efficacy in Grignard reactions (nucleophilic additions to carbonyl group). Reaction of excess $\mathrm{TMSCH}_{2} \mathrm{MgCl}(\geq 110 \mathrm{~mol} \%$ ) with acetophenone led to the formation of the corresponding $\beta$ hydroxysilane. We decided to examine the scope of the reaction of excess $\mathrm{TMSCH}_{2} \mathrm{MgCl}$ further with other aryl enolizable ketones to yield the corresponding $\beta$-silylalkoxides.

Enolizable aryl ketones were added to a heterogeneous mixture of $130 \mathrm{~mol} \%$ trimethylsilylmethyl magnesium chloride ( $1 \mathrm{M}$ in diethyl ether), $10 \mathrm{~mol} \% \mathrm{ZnCl}_{2}$ and $170 \mathrm{~mol} \% \mathrm{LiCl}$ (Scheme 4). The original protocol called for the use of THF as solvent. Our preliminary study focused on the reaction with acetophenone by subjecting acetophenone to the reaction protocol with and without the use of THF as solvent. The reported protocol called for 2 hours stirring at $0{ }^{\circ} \mathrm{C}$ after dropwise addition of ketone also at $0{ }^{\circ} \mathrm{C}$. Our results suggested that the reaction can be allowed to stir overnight (ca. $12 \mathrm{~h}$ ) without significant formation of side-products, even in the absence of THF solvent. Diethyl ether from the (trimethylsilyl)methyl magnesium chloride solution (1 M) appears to suffice as solvent to facilitate the formation of $\beta$ silylalkoxides.

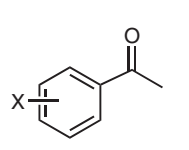

$\mathrm{X}=\mathrm{H}$, 4-halo,4- and 2-Me, 4-Et, 4-MeO

Scheme 4

A mixture of hexanes was also examined as a possible solvent. While no significant difference was observed in the first reaction step (converting the enolizable ketones into their corresponding $\beta$-silylalkoxides), the subsequent elimination reaction generally required longer reaction times and higher temperatures.
To carry out the abnormal Peterson reaction of the $\beta$-silylalkoxides, diisobutylaluminum chloride was added followed by THF. The resulting mixture was transferred by using a cannula into a sealed tube under argon and the mixture was heated at $130{ }^{\circ} \mathrm{C}$ for 15 hours (Scheme 5 ), followed by washing with saturated aqueous sodium tartrate and work-up. The results are summarized in Table 1.

Table 1 Two Step, One-Pot Synthesis of Allysilane from Aryl Methyl Ketones

\begin{tabular}{|c|c|c|c|}
\hline \multirow[t]{2}{*}{ Entry } & \multirow[t]{2}{*}{ Aryl methyl ketones } & \multicolumn{2}{|l|}{ Yield (\%) ${ }^{\mathrm{a}}$} \\
\hline & & Allysilane & Olefin \\
\hline 1 & $X=4-H$ & $58^{10}$ & $8^{11}$ \\
\hline 2 & $X=4-F$ & $71^{10}$ & $0^{12}$ \\
\hline 3 & $\mathrm{X}=4-\mathrm{Cl}$ & $63^{13}$ & $0^{14}$ \\
\hline 4 & $\mathrm{X}=4-\mathrm{Br}$ & $68^{15}$ & $0^{12}$ \\
\hline 5 & $\mathrm{X}=4-\mathrm{OCH}_{3}$ & $43^{16}$ & $32^{12}$ \\
\hline 6 & $\mathrm{X}=4-\mathrm{CH}_{3}$ & $43^{16}$ & $7^{14}$ \\
\hline 7 & $\mathrm{X}=4-\mathrm{CH}_{2} \mathrm{CH}_{3}$ & $64^{16}$ & $11^{17}$ \\
\hline 8 & $\mathrm{X}=2-\mathrm{CH}_{3}$ & $\begin{array}{l}\text { multiple } \\
\text { + olefin }\end{array}$ & oducts + allylsilane \\
\hline
\end{tabular}

${ }^{\mathrm{a}}$ References for ${ }^{1} \mathrm{H}$ NMR spectroscopic comparison.

The Ishihara study ${ }^{8 d}$ briefly examined the use of the trimethylsilylmethyl group $\left(\left(\mathrm{CH}_{3}\right)_{3} \mathrm{SiCH}_{2^{-}}\right)$as the alkylating agent. We modified the reported protocol slightly and used it to alkylate substituted aryl methyl ketones in the first step, yielding the corresponding $\beta$-silylalkoxides. Heating the reaction mixture containing the silylalkoxide derived from acetophenone (Table 1, entry 1 ) reaction in THF (without adding diisobutylaluminum chloride) simply produced the corresponding $\beta$-hydroxysilane. This indicates that additional amphoteric reagent, diisobutylaluminum chloride, is required for the abnormal Peterson olefination to yield the corresponding allylsilanes. Diisobutylaluminum chloride was used rather than less bulky diethylaluminum chloride since, in the acetophenone reaction (entry 1 ), the latter yielded a greater amount of olefin product.

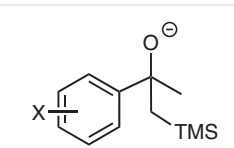

$\beta$-silylalkoxides

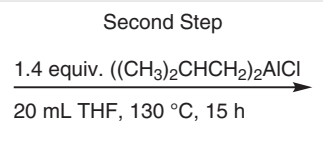

$\mathrm{X}=\mathrm{H}, 4$-halo, 4- and 2-Me, 4-Et, 4-MeO

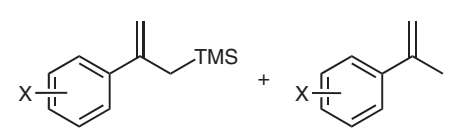

allylsilanes olefins 
p-Haloaryl methyl ketones afforded the corresponding allylsilanes in acceptable yields with high chemoselectivity. Reactions of electron-rich ketones (Table 1, entry 5-7) afforded a mixture of the corresponding allylsilanes and olefins. It is worth noting that the most electron-rich ketone (entry 5) produced the highest amount of the corresponding olefin. To determine in which step the corresponding olefin is produced in the two-step, one-pot synthesis, we ran a series of alkylation reactions to produce $\beta$-hydroxysilanes for each ketone. Reactions of electron-rich ketones yielded a mixture of $\beta$-silylalcohols and olefins while $p$ haloaryl methyl ketones yielded primarily $\beta$-silylalcohols. Alkylation of $o$-methylaryl methyl ketone gave multiple products such as aldol addition products, olefins, and $\beta$-silylalcohols.

Applying the developed protocol with 2-methylacetophenone afforded multiple products (Table 1 , entry 8 ). To understand the system better, we applied Ishihara's protocol in attempts to convert 2-methyl-, 2-fluoro-, and 3methylacetophenone into their corresponding $\beta$-hydroxysilanes (Scheme 6). Repeated reactions yielded multiple products from these three ketones. ${ }^{1} \mathrm{H}$ NMR spectroscopic and TLC analyses indicated a minimum of three components in the mixture: recovered ketone, self-aldol condensation product, and $\beta$-hydroxysilane. Thus, our attempts to prepare allylsilanes were ineffective with these three ketones. We also examined the developed protocol with 4-nitroacetophenone but, given the vulnerability of the nitro group to nucleophilic attack from the Grignard reagent, it is not surprising that the reaction failed to produce the corresponding allylsilane product. ${ }^{18}$

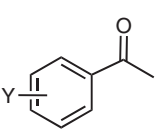

1) $10 \mathrm{~mol}_{2} \mathrm{ZnCl}_{2}$

$170 \mathrm{~mol} \% \mathrm{LiCl}$

$130 \mathrm{~mol} \% \mathrm{TMSCH}_{2} \mathrm{MgCl}$

2) $\mathrm{H}_{2} \mathrm{O}$

$\mathrm{Y}=2-\mathrm{Me}, 3-\mathrm{Me}, 2-\mathrm{F}, 4-\mathrm{NO}_{2}$

Scheme 6

In conclusion, we have employed and slightly modified the method for alkylation of enolizable ketones developed by Ishihara to alkylate a series of methyl aryl ketones with a trimethylsilylmethyl $\left(\left(\mathrm{CH}_{3}\right)_{3} \mathrm{SiCH}_{2}-\right)$ group to generate $\beta$-silylalkoxides as the first step of our one-pot allylsilane synthesis protocol. The second step entails addition of diisobutylaluminum chloride with heating, leading to the abnormal Peterson olefination reaction, affording allylsilanes in fair yield. ${ }^{19}$ This one-pot synthesis works particularly well with $p$-haloaryl methyl ketones.

\section{Funding Information}

We gratefully acknowledge the funding support of the John Carroll University Summer Undergraduate Research Fellowship (funded by the Colleran-Weaver Research Fellowships).

\section{Supporting Information}

Supporting information for this article is available online at https://doi.org/10.1055/s-0039-1690335.

\section{References and Notes}

(1) For examples of synthetic uses of allylsilanes, see: (a) Brook, M. A. Silicon in Organic, Organometallic, and Polymer Chemistry; Wiley: Chichester, 2000. (b) Fleming, I.; Dunoguès, J.; Smithers, R. Organic Reactions; John Wiley \& Sons, Inc: New York, 2004, 57-575. (c) Hosomi, A.; Endo, M.; Sakurai, H. Chem. Lett. 1976, 5, 941. (d) Fleming, I.; Barbero, A.; Walter, D. Chem. Rev. 1997, 97, 2063. (e) Hosomi, A.; Sakurai, H. Tetrahedron Lett. 1976, 1295. (f) Sakurai, H.; Hosomi, A.; Hayashi, J. Org. Synth. 1984, 62, 86. (g) Masse, C. E.; Panek, J. S. Chem. Rev. 1995, 95, 1293. (h) Denmark, S. E.; Fu, J. Chem. Rev. 2003, 103, 2763.

(2) For examples of the preparation of allylsilanes, see: (a) Hayashi, S.; Hirano, K.; Yorimitsu, H.; Oshima, K. J. Am. Chem. Soc. 2007, 129, 12650. (b) Murakami, K.; Yorimitsu, H.; Oshima, K. J. Org. Chem. 2009, 74, 1415. (c) Bhushan, V.; Lohray, B. B.; Enders, D. Tetrahedron Lett. 1993, 34, 5067. (d) Bunnellem, W. H.; Narayanan, B. A. Tetrahedron Lett. 1987, 28, 6261. (e) Fleming, I.; Marchi, D. Synthesis 1981, 560.

(3) Batesky, D. C.; Goldfogel, M. J.; Weix, D. J. J. Org. Chem. 2017, 82, 9931.

(4) Peterson, D. J. J. Org. Chem. 1968, 33, 780.

(5) Kwan, M. L.; Battiste, M. A. Tetrahedron Lett. 2002, 43, 8765.

(6) Kwan, M. L.; Yeung, C. W.; Breno, K. L.; Doxsee, K. M. Tetrahedron Lett. 2001, 42, 1411.

(7) Elimination of the $\beta$-silyl alkoxides with alanes (not Tebbe's reagent) requires higher temperatures and prolonged reflux time (several days).

(8) (a) Imamoto, T.; Takiyama, N.; Nakamura, K.; Hatajima, T.; Kamiya, Y. J. Am. Chem. Soc. 1989, 111, 4392. (b) Krasovskiy, A.; Kopp, F.; Knochel, P. Angew. Chem. Int. Ed. 2006, 45, 497. (c) Metzger, A.; Gavryushin, A.; Knochel, P. Synlett 2009, 1433. (d) Hatano, M.; Ito, O.; Suzuki, S.; Ishihara, K. J. Org. Chem. 2010, $75,5008$.

(9) Lucas, H. J. J. Am. Chem. Soc. 1930, 52, 802.

(10) Mo, J.; Xu, L.; Xiao, J. J. Am. Chem. Soc. 2005, 127, 751.

(11) Pandey, S. K.; Greene, A. E.; Poisson, J. J. Org. Chem. 2007, 72, 7769.

(12) Fryszkowska, A.; Fisher, K.; Gardiner, J. M.; Stephens, G. M. J. Org. Chem. 2008, 73, 4295.

(13) Liu, J.; Chu, L.; Qing, F.-L. Org. Lett. 2013, 15, 894.

(14) Gupton, J. T.; Layman, W. J. J. Org. Chem. 1987, 52, 3683.

(15) Walkowiak, J.; Martinez del Campo, T.; Ameduri, B.; Gouverneur, V. Synthesis 2010, 1883.

(16) Cai, G.; Zhou, Z.; Wu, W.; Yao, B.; Zhang, S.; Li, X. Org. Biomol. Chem. 2016, 14, 8702.

(17) Isagulyants, V. I.; Kustanovich, Z. D.; Dessuki, A. M. Zh. Prikl. Khim. 1967, 40, 1355.

(18) For examples of reactions of Grignard reagents with nitro-compounds, see: (a) Gilman, H.; McCracker, R. J. Am. Chem. Soc. 1929, 51, 821. (b) Bartoli, G.; Bosco, M.; Dalpozzo, R. Tetrahedron Lett. 1985, 26, 115. (c) Sapountzis, I.; Knochel, P. Angew. Chem. Int. Ed. 2002, 41, 1610.

(19) Allylsilane Synthesis; General Procedure

To a $100 \mathrm{~mL}$ Schlenk flask, $\mathrm{ZnCl}_{2}$ (10 mol\%) was added and meltdried with a heat gun under reduced pressure ( 5 Torr, $5 \mathrm{~min}$ ). $\mathrm{LiCl}$ (170 mol\%) was then added, followed by heating with a 
heat gun under reduced pressure ( 5 Torr, $5 \mathrm{~min}$ ). After cooling back to room temperature, trimethylsilylmethyl magnesium chloride (1 M in diethyl ether; $130 \mathrm{~mol} \%$ ) was added to the mixed dried salts under argon. The resulting heterogeneous mixture was allowed to stir for $15 \mathrm{~min}$ at room temperature followed by cooling to $0{ }^{\circ} \mathrm{C}$. The requisite aryl methyl ketone (500 $\mathrm{mg}$ ) was added dropwise by using a syringe to the heterogeneous mixture over $1 \mathrm{~h}$ at $0{ }^{\circ} \mathrm{C}$ and the resulting mixture was allowed to stir for an additional $2 \mathrm{~h}$ at $0{ }^{\circ} \mathrm{C}$. Diisobutylaluminum chloride (140 mol\%) and anhydrous THF (20 mL) were then added to the mixture at $0{ }^{\circ} \mathrm{C}$. This mixture was then transferred by using a cannula from the $100 \mathrm{~mL}$ Schlenk flask to a $150 \mathrm{~mL}$ pressure flask. The pressure flask was capped and heated at $130{ }^{\circ} \mathrm{C}$ for $15 \mathrm{~h}$. The reaction was quenched by washing the mixture with $10 \%$ sodium tartrate solution and the mixture was extracted with diethyl ether. The ether extract was dried over $\mathrm{MgSO}_{4}$. Gravity filtration followed by solvent evaporation gave oily allyl silane products.

[(2-Phenyl)allyl]trimethylsilane (1): ${ }^{1} \mathrm{H}$ NMR (300 $\mathrm{MHz}$, $\left.\mathrm{CDCl}_{3}\right): \delta=7.42-7.20(\mathrm{~m}, 5 \mathrm{H}), 5.14(\mathrm{~d}, J=1.8 \mathrm{~Hz}, 1 \mathrm{H}), 4.88$ (d, $J=1.8 \mathrm{~Hz}, 1 \mathrm{H}), 2.03(\mathrm{~d}, J=1.2 \mathrm{~Hz}, 2 \mathrm{H}),-0.09(\mathrm{~s}, 9 \mathrm{H})$.
[2-(4-Fluorophenyl)allyl]trimethylsilane (2): ${ }^{1} \mathrm{H}$ NMR (300 $\left.\mathrm{MHz}, \mathrm{CDCl}_{3}\right): \delta=7.34-7.30(\mathrm{~m}, 2 \mathrm{H}), 7.00-6.85(\mathrm{~m}, 2 \mathrm{H}), 5.05(\mathrm{~d}$, $J=1.8 \mathrm{~Hz}, 1 \mathrm{H}), 4.83(\mathrm{~s}, 1 \mathrm{H}), 1.97(\mathrm{~d}, J=0.9 \mathrm{~Hz}, 2 \mathrm{H}),-0.12(\mathrm{~s}, 9$ $\mathrm{H})$

[2-(4-Chlorophenyl)allyl]trimethylsilane (3): ${ }^{1} \mathrm{H}$ NMR (300 $\left.\mathrm{MHz}, \mathrm{CDCl}_{3}\right): \delta=7.35-7.28(\mathrm{~m}, 4 \mathrm{H}), 5.11(\mathrm{~d}, J=1.5 \mathrm{~Hz}, 1 \mathrm{H})$, $4.87(\mathrm{~d}, J=0.9 \mathrm{~Hz}, 1 \mathrm{H}), 1.98$ (d, J = 0.9 Hz, $2 \mathrm{H}), 0.10(\mathrm{~s}, 9 \mathrm{H})$. [2-(4-Bromophenyl)allyl]trimethylsilane (4): ${ }^{1} \mathrm{H}$ NMR (300 $\left.\mathrm{MHz}, \mathrm{CDCl}_{3}\right): \delta=7.47-7.26(\mathrm{~m}, 4 \mathrm{H}), 5.12(\mathrm{~d}, J=1.8 \mathrm{~Hz}, 1 \mathrm{H})$, $4.89(\mathrm{~d}, J=1.5 \mathrm{~Hz}, 1 \mathrm{H}), 1.98(\mathrm{~d}, J=0.9 \mathrm{~Hz}, 2 \mathrm{H}),-0.08(\mathrm{~s}, 9 \mathrm{H})$. [2-(4-Methoxyphenyl)allyl] trimethylsilane (5): ${ }^{1} \mathrm{H}$ NMR (300 $\mathrm{MHz}, \mathrm{CDCl}_{3}$ ): $\delta=7.44-7.26(\mathrm{~m}, 2 \mathrm{H}), 6.90-6.80(\mathrm{~m}, 2 \mathrm{H}), 5.10$ (s, $1 \mathrm{H}), 4.79(\mathrm{~s}, 1 \mathrm{H}), 3.80(\mathrm{~s}, 3 \mathrm{H}), 1.98(\mathrm{~s}, 2 \mathrm{H}),-0.08(\mathrm{~s}, 9 \mathrm{H})$.

[2-(4-Methylphenyl)allyl]trimethylsilane (6): ${ }^{1} \mathrm{H}$ NMR (300 $\left.\mathrm{MHz}, \mathrm{CDCl}_{3}\right): \delta=7.44-7.11(\mathrm{~m}, 4 \mathrm{H}), 5.13(\mathrm{~d}, J=1.8 \mathrm{~Hz}, 1 \mathrm{H})$, $4.84(\mathrm{~s}, 1 \mathrm{H}), 3.56(\mathrm{~s}, 3 \mathrm{H}), 1.98$ (s, $2 \mathrm{H}),-0.08(\mathrm{~s}, 9 \mathrm{H})$.

[2-(4-Ethylphenyl)allyl]trimethylsilane (7): ${ }^{1} \mathrm{H}$ NMR (300 $\left.\mathrm{MHz}, \mathrm{CDCl}_{3}\right): \delta=7.44-7.11(\mathrm{~m}, 4 \mathrm{H}), 5.12(\mathrm{~d}, J=1.5 \mathrm{~Hz}, 1 \mathrm{H})$, $4.84(\mathrm{~d}, J=0.9 \mathrm{~Hz}, 1 \mathrm{H}), 2,65(\mathrm{~m}, 2 \mathrm{H}), 2.08(\mathrm{~s}, 2 \mathrm{H}), 1.25(\mathrm{~m}, 3 \mathrm{H})$, $-0.08(\mathrm{~s}, 9 \mathrm{H})$ 